\title{
Correction to: Identification of Brassica napus small RNAs responsive to infection by a necrotrophic pathogen
}

Roshan Regmi ${ }^{1}{ }^{2 *}$, Toby E. Newman ${ }^{1}$, Lars G. Kamphuis ${ }^{1,2}$ and Mark C. Derbyshire ${ }^{1 *}$

Correction to: BMC Plant Biol 21, 366 (2021)

https://doi.org/10.1186/s12870-021-03148-6

Following publication of the original article [1], the author has found two mistakes in the title made by the BMC production office. The title of the original article and this erratum have been changed from 'fIdentification of $B$. napus small RNAs responsive to infection by a necrotrophic pathogen' to 'Identification of Brassica napus small RNAs responsive to infection by a necrotrophic pathogen.

The original article has been corrected.

\section{Author details}

${ }^{1}$ Centre for Crop and Disease Management, School of Molecular and Life Sciences, Curtin University, Bentley, WA 6102, Australia. ${ }^{2}$ Commonwealth Scientific and Industrial Research Organisation Agriculture and Food, Floreat, WA 6014, Australia.

Published online: 26 August 2021

\section{Reference}

1. Regmi R, Newman TE, Kamphuis $L G$, et al. Identification of B. napus small RNAs responsive to infection by a necrotrophic pathogen. BMC Plant Biol. 2021;21:366. https://doi.org/10.1186/s12870-021-03148-6.

\footnotetext{
The original article can be found online at https://doi.org/10.1186/s12870021-03148-6.

* Correspondence: roshan.regmi@postgrad.curtin.edu.au; mark.derbyshire@curtin.edu.au

${ }^{1}$ Centre for Crop and Disease Management, School of Molecular and Life Sciences, Curtin University, Bentley, WA 6102, Australia

Full list of author information is available at the end of the article
}

(c) The Author(s). 2021 Open Access This article is licensed under a Creative Commons Attribution 4.0 International License, which permits use, sharing, adaptation, distribution and reproduction in any medium or format, as long as you give appropriate credit to the original author(s) and the source, provide a link to the Creative Commons licence, and indicate if changes were made. The images or other third party material in this article are included in the article's Creative Commons licence, unless indicated otherwise in a credit line to the material. If material is not included in the article's Creative Commons licence and your intended use is not permitted by statutory regulation or exceeds the permitted use, you will need to obtain permission directly from the copyright holder. To view a copy of this licence, visit http://creativecommons.org/licenses/by/4.0/. The Creative Commons Public Domain Dedication waiver (http://creativecommons.org/publicdomain/zero/1.0/) applies to the data made available in this article, unless otherwise stated in a credit line to the data. 